УДК 78.071.2(477) “ХХІ”

DOI:

Ірина Гринчук, кандидат педагогічних наук, доцент кафедри музикознавства та методики музичного мистецтвва факультету мистецтв Тернопільського національного педагогічного університету імені В. Гнатюка

Емілія Горук, викладач-методист Теребовлянського коледжу культури і мистецтв Ярослава Кубіт, викладач-методист Теребовлянського коледжу культури і мистецтв

\title{
ПОПУЛЯРИЗАЦІЯ ВИКОНАВСТВА НА НАРОДНИХ ІНСТРУМЕНТАХ У СУЧАСНОМУ КУЛЬТУРНО-ОСВІТНЬОМУ ПРОСТОРІ УКРАЇНИ
}

Піднято проблему розвитку та популяризачї виконавства на народних інструментах у контексті сучасних соиіокультурних та освітніх проиесів. Увагу зосереджено на представленні музичних колективів Украӥни із залученням народних інструментів, як академічного напрямку, так і молодіжних популярних груп та виконавців. Розглянуто діяльність відомих представників Тернопілля: інструментальних капел та малих форм, студентських інструментальних капел та оркестрів, виконавців-інструменталістів, які внесли вагому лепту у популяризацію виконавства на народних інструментах.

Ключові слова: культурно-освітні процеси в Украӥні; початок XXI ст.; виконавство на народних інструментах; музичні колективи; виконавиі-інструменталісти.

Jim. 5.

Iryna Hrynchuk, Ph. D.(Pedagogy), Associate Professor of the Musicology and Methods of Music Art Department

Ternopil Volodymyr Hnatyuk National Pedagogical University Emiliya Horuk, Lecturer and Methodologist of Terebovlyany College of Culture and Arts Yaroslava Kubit, Lecturer and Methodologist of Terebovlyany College of Culture and Arts

\section{POPULARIZATION OF PERFORMANCE ON NATIONAL INSTRUMENTS IN MODERN CULTURAL AND EDUCATIONAL SPACE OF UKRAINE}

There have been considered the state and perspectives of propagation of the performance on folk instruments, on the bandura in particular, in the youth cultural environment and modern educational practice of Ukraine, Ternopil region in particular.

There has been raised the problem of popularization of the performance on folk instruments in the context of modern socio-cultural and educational processes.

It is noted that contemporary performing arts on folk instruments reflected the characteristic tendencies of Ukrainian art development at the end of the 20th - beginning of the 21st century. It is based on the established educational base of Ukrainian artistic institutions of different levels of accreditation, on the extensive concert and festival network. The solo instrumental, vocal-instrumental and ensemble performance has been actively developed and a galaxy of performers has been established conducting active concert activities in Ukraine and abroad.

Attention is focused on the representation of Ukrainian musical groups with the involvement of folk instruments, both academic and the youth popular groups and performers.

It is emphasized that during the period of popularization of the performance on folk instruments, the appeal to the sphere of mass culture and the interpretation of world "hits" and cover versions, the active participation of instrumentalists in show projects and festivals, in international contests, etc., is becoming characteristic new forms of youth music: the so called "club projects", "apartment concerts", theme parties, joint performances with famous rock or pop musicians, etc.

There has been analysed the activities of famous representatives of Ternopil region: instrumental chapels, the student instrumental chapels and orchestras, instrumental performers, who contributed greatly to the popularization of the performance on folk instruments.

Among them there are the Strusiv Bandurist Choir "Kobzar" and the studio "Kobzaryk", the bandura chapel "Mriya" (Chortkiv), the "Vatrivchany" ensemble, the "Oriana" trio (subsequently the quartet), the "Roxolana", "Stritennia", the duet "Elegy of Strings", creative collectives operating in educational institutions of Ternopil and Ternopil Region. More thoroughly there has been presented concert and festival competition activity of instrumental groups at the Ternopil Volodymyr Hnatyuk National Pedagogical University, Terebovyany College of Culture and Arts.

Keywords: cultural and educational processes in Ukraine; beginning of the XXI century; performance on folk instruments; musical collectives; instrumental performers. 


\section{ПОПУЛЯРИЗАЦІЯВИКОНАВСТВАНАНАРОДНИХ ІНСТРУМЕНТАХ}

У СУЧАСНОМУ КУЛЬТУРНО-ОСВІТНЬОМУ ПРОСТОРІ УКРАЇНИ

народних інструментах як складової традиційної та академічної виконавської культури.

У цьому контексті важливим напрямком $\epsilon$ дослідження форм, різновидів виконавства на народних інструментах (М. Давидов [3], Д. Кужелєв, О. Олексюк та ін.). Вагомими є наукові розвідки 3 проблем бандурного виконавства як в Україні, так і діаспорі (В. Дутчак, Н. Морозевич, Н. Ніколенко, І. Зінків, І. Лісняк та ін.), зокрема на Тернопіллі (О. Ваврик (Дубас), М. Свгеньєва, Д. Губ’як [1;2] та ін.).

Матеріали наукових конференцій, монографічних досліджень, енциклопедичних (В. Смець, Б. Жеплинський та ін.) та періодичних видань, аудіо- й відеозаписи виступів інструменталістів, вивчення сучасної концертної, фестивальної практики, інтерв'ю з відомими педагогами та виконавцями дозволяють прослідкувати процеси розвитку та популяризації бандурного мистецтва України, зокрема Тернопілля, узагальнокультурному контексті, у просвітницькому, аматорському та фаховому середовищах.

Метою статті $\epsilon$ представлення діяльності відомих сучасних інструментальних колективів академічного напрямку, молодіжних популярних груп та виконавців-інструменталістів у контексті сучасних соціокультурних та освітніх процесів в Україні.

Завдання статті - розглянути стан та перспективи поширення виконавства на народних інструментах, зокрема на бандурі, у молодіжному культурному середовищі України, у сучасній навчальній практиці Тернопілля.

Виклад основного змісту. Сучасне виконавське мистецтво на народних інструментах відобразило характерні тенденції розвитку українського музичного мистецтва кінця XX початку XXI ст., опираючись на сформовану методологічну і методичну освітню базу низки мистецьких закладів України різного рівня акредитації, на розгалужену концертнофестивальну мережу.

Так, на межі тисячоліть активного розвитку набуло сольне інструментальне, вокальноінструментальне, ансамблеве виконавство, утвердилася плеяда виконавців на народних інструментах, які проводять активну концертну діяльність в Україні та за їі межами, здійснено конструктивні модифікації інструментів різних типів, що дозволяє створювати і виконувати складний різноплановий оригінальний та аранжований репертуар.

Сучасне інструментальне виконавське мистецтво у своїх фахових і художніх засадах утвердилось як невід’ $є$ мна складова частина національної академічної музичної культури. Так, школою професіоналізму для багатьох виконавців-інструменталістів стали: Оркестр українських народних інструментів Національної радіокомпанії України, Національний академічний оркестр народних інструментів України, Національна заслужена капела бандуристів України ім. Г. Майбороди, інструментальні складові низки відомих в Україні та за їі межами хорових колективів (Національний заслужений академічний народний хор України ім. Г. Верьовки, Черкаський академічний заслужений український народний хор та ін.), окремі інструментальні та вокально-інструментальні капели, як заслужена капела бандуристів “Кобзар" (Струсів) [1], колективи різних інструментальних складів при обласних філармоніях, Палацах культури, навчальних мистецьких закладах та ін.

Зазначимо, що важливим мотивуючим чинником для популяризації виконавства на народних інструментах у сучасному молодіжному середовищі, у практиці фахової музичної освіти на різних іiі рівнях значною мірою сприяє активна сучасна концертна, фестивально-конкурсна практика солістів та ансамблістів [5].

Серед колективів з участю бандуристів, відомих в Україні та за іï межами, слід назвати наступні: чоловічий дует зі Львова "Бандурна розмова” (створений 1994 р.); квартет “Львів'янки” (створений 2000 р. при Львівській національній музичній академії ім. М. Лисенка, 3 2004 р. - при філармонії); тріо “Мальви” (створене 1993 р. при Одеській державній музичній академії ім. А. Нежданової, з 1994 р. - при філармонії).

Серед популярних тріо - колективи обласних філармоній: “Купава”, “Вишиванка” (Полтава), “Дивоструни” (Луцьк), “YuMaVita”, Bandura Trio (Львів), “Пектораль”, квартет “Гердан” (ІваноФранківськ), “Оріана”, “Елегія струн” (Тернопіль) та ін.

Як зазначають музикознавці-дослідники (I. Лісняк [5] та ін.), саме в інструментальному мистецтві малих вокально-інструментальних колективів мішаного складу найбільшою мірою представлені оригінальні ідеї, авангардні пошуки сучасних митців. Як приклад: дует Т. Гордійчук та I. Сиротюк (бандура, баян) (Одеса), дует “Діалоги” (бандура, баян, Надія та Свген Свенко), дует Людмили та Юрія Федорових (ІваноФранківськ), тріо “Срібна терція” (Рівне), більші форми - "Creschendo оркестр" (згодом “SHARAVARABAND”), ансамбль “Прем' $є$ " та ін. (I. Лісняк [5]).

Можемо прослідкувати, що у згаданих 


\section{ПОПУЛЯРИЗАЦІЯВИКОНАВСТВАНА НАРОДНИХ ІНСТРУМЕНТАХ}

інструментальних формах успішно поєднані академічні і народні інструменти (домри, цимбали, баян, згодом бандура), епізодично ударна установка. Інструментальні колективи із залученням народних інструментів звертаються до різностильового й різножанрового репертуару, активно експериментують, синтезують у своїй творчості елементи масової музики, прагнучи “подолати” стереотипні уявлення про “виключно фольклорні” інструменти. Так, Національний академічний оркестр народних інструментів України успішно виступив на концерті конкурсу "Свробачення" разом із електрогрупою “ONUKA” (2017р., Київ).

Зазначимо, що для творчості виконавцівінструменталістів, які звертаються до сфери масової культури, характерним $\epsilon$ звернення до інтерпретації світових хітів, написання каверверсій, що сприяє популяризації народних інструментів, зокрема бандури, в середовищі широкої аудиторії. Цьому сприяє і активна участь виконавців на народних інструментах у шоупроектах та фестивалях, серед яких "Україна має талант”, “Голос Країни”, “Країна Мрій” та ін.

Окремими новітніми формами популяризації народних інструментів у молодіжному середовищі стали т. зв. “клубні проекти”, “квартирники”, тематичні вечірки, спільні виступи з відомими рок-, поп- музикантами та ін. Вплив масової культури проявляється сьогодні у низці факторів: згадані вище нові форми музикування, оновлення репертуару, новий “сценічний імідж” музикантів, використання вертикальних підставок для утримання інструментів, світлових ефектів, застосування звукознімачів та ін. Так, на базі ТНПУ відбулася презентація електробандури (конструкція бандуриста I. Ткаленка) у виконанні Д. Губ'яка.

Прикладом модерного підходу є репертуар Р. Гринькіа, який спільно з рок-групою “Димна Суміш" записали 30-ти хвилинний альбом імпровізацій "Live Improvisation" (2010), співпрацює з такими зірками українського шоубізнесу, як Руслана, О. Скрипка, Ілларія, Джамала та ін. Успішними творчими тандемами стали виступи В. Лисенка зі співачкою Т. Матвієнко, Я. Джуся - з Катею Chilli, рок-групою “Веремія”, М. Круть - із В. Павліком та ін.

Цікаві кавер-версії та оригінальні авторські твори виконують інструментальні складі ансамблів за участю бандури, зокрема, "Eleven 11", "MUSIC Project" (Одеса), "B\&B Project" (Київ), "Mosaic", "Ptakha". Показовим прикладом $\epsilon$ ансамбль “ЦимБанДо і Ко” (Харків): Цимбали, Бандура, Домра та балалайка-контрабас; гурт
“День Неба": бандура, гітара та ударні; гурт "Marina Krut Project" (далі "KRUT"): бандура, барабани, 2 гітари, труба [5]. У подібному руслі творять проекти дует сестер Тельнюк, гурти "Небо" і “Тінь Сонця", “Шпилясті кобзарі" (Я. Джусь) та ін.

Виконавська практика засвідчує про інтерес до використання тембру бандури в рок-музиці (від 2000-х рр.), до синтезу різних стильових напрямів сучасної масової музики, експерименту з такими стилями, як folk, ethno, jazz-folk та ін. До процесу синтезування різних стилів та жанрів долучаються і виконавці на реконструйованих автентичних інструментах. Прикладом $\epsilon$ діяльність В. Кушпета та його учня С. Захарця, виступи “Козацької хореї” та ін., у яких оригінально поєднано тембри старосвітських та електронних інструментів. Окремий пласт виконавців, які сприяють популяризації народних інструментів, представляють сучасні виконавці авторської пісні, серед яких дипломанти “Червоної рути” В. Лютий (1997), О. Цеацура (1998) та ін. [5].

Серед “знакових" колективів Тернопілля, які спряли розвитку і популяризації виконавства на народних інструментах, зокрема, і на бандурі, слід назвати чоловічу капелу бандуристів с. Струсів Теребовлянського району (сьогодні - Струсівська заслужена капела бандуристів України "Кобзар”) [1]. При цьому колективі діяла студія “Кобзарик”, керівник - Я. Кубіт [1], яка виховала низку відомих бандуристів, лауреатів конкурсів, серед них згадуваний вище заслужений артист України Д. Губ'як, О. Воробйов, У. Перхалюк та ін.

Популяризації виконавства на народних інструментах сприяє гнучке поєднання навчальної, культурно-виховної та концертно-фестивальної діяльності студентів. Так, вихованці спеціалізації "Народне інструментальне мистецтво (народні інструменти)” Теребовлянського коледжу, автори статті Я. Кубіт, Е. Горук як концертмейстери оркестру народних інструментів, приймали участь у низці мистецьких форумів: у IV міжнародному фольклорному фестивалі етнографічних регіонів України “Родослав" (Івано-Франківськ, 2012 р.); у VIII, IX міжнародних конкурсах баяністівакордеоністів “Perpetuum Mobile" (Дрогобич, 2015 - 2016 рр.), у Всеукраїнському конкурсі бандурного мистецтва “Золоті струни” (2015 р.), зокрема, М. Антонюк (клас Я. Кубіт).

Так, у Всеукраїнському творчому фестиваліконкурсі молодих виконавців вокальної, інструментальної музики та художнього слова “Шукаємо та ростимо таланти України" (Житомир, 2018 р.) були відзначені дует баяністів Ю. Гладкий та Р. Репетинський (III-є місце, клас 


\section{ПОПУЛЯРИЗАЦІЯВИКОНАВСТВАНАНАРОДНИХ ІНСТРУМЕНТАХ}

\section{У СУЧАСНОМУ КУЛЬТУРНО-ОСВІТНЬОМУ ПРОСТОРІ УКРАЇНИ}

викладача-методиста Р.М. Подільського), Ю. Гладкий як соліст (I-е місце), випускник T. Парацій (III-є місце, акордеон, клас викладача Н.О. Зелінської).

У регіональному конкурсі "MusicUniFest" (м. Кам'янець-Подільськ) були відзначені студенти А. Твердохліб (I-е місце, баян, клас викладача заслуженого працівника культури B.I. Сороки), Г. Стахів (клас викладача М. Губ'як), М. Волошин (клас викладача У. Перхалюк).

Коледж пишається своїми випускниками, які успішно популяризують народно-інструментальне виконавство в Україні, за її межами. Серед них: лауреати Всеукраїнських та Міжнародних конкурсів дует “Браво” В. Лутчак та 3. Кіт (клас викладачів В. Шевчука, Р. Подільського), які успішно працюють в ЦКіД (м. Косів); випускниці Я. Кубіт, зокрема, О. Степанова, яка $є$ мистецьким керівником ансамблю “Заграва”, лауреата Міжнародних і Всеукраїнських конкурсів (м. Південне, Одеська область), С. Плотник, яка є мистецьким керівником ансамблю бандуристів “Дніпрові хвилі” (Торонто, Канада) та ін.

Популяризації інструментального виконавства сприяє діяльність відомих капел краю, серед яких народна самодіяльна мішана капела бандуристів "Мрія" (Чортківський РБК), жіноча капела "Веснянка" при Тернопільському музичному коледжі (ТМК) ім. С. Крушельницької, мішана капела при Кременецькій обласній гуманітарнопедагогічній академії (КОГПА) ім. Т. Шевченка, ансамбль Тернопільського національного економічного університету (ТНЕУ) (з 2011 р. “Калинове намисто”) [4], ансамблі Тернопільського національного педагогічного університету (ТНПУ) ім. В. Гнатюка [2].

На сьогодні, окрім згаданих вище, активно функціонують оркестри народних інструментів при Чортківському гуманітарно-педагогічноу училищі ім. О. Барвінського, Теребовлянському коледжі культури і мистецтв, коледжі при КОГПА ім. Т. Шевченка та ін. [4].

Ці колективи - учасники і переможці творчих змагань, серед яких: обласний фестиваль-конкурс кобзарського мистецтва “Кобза”(2005 та 2008 рр.), регіональний фестиваль кобзарського мистецтва “Кобзарські сезони Волині” (м. Кременець, 2005), регіональні фестивалі-конкурси кобзарського мистецтва "Козацька ватра" ім. К. Місевича (2009-2010 рр., автор проекту Д. Губ’як), Всеукраїнський фестиваль-конкурс “Срібні струни” (2000), який отримав ім’я 3. Штокалка (2006, 2011 та 2013 рр.). Ці та інші мистецькі форуми сприяли професіоналізації виконавства на народних інструментах, популяризації сольного та ансамблевого виконавства на теренах Західної України [2; 4].

Коротко представимо роль у популяризації виконавства на народних інструментах заслуженого артиста України, доцента Д. Губ'яка, який від 2010 р. веде клас бандури і ансамблю при ТНПУ ім. В. Гнатюка [2]. Студенти його класу беруть активну участь у мистецькому та концертному житті міста, виборюють призові місця на всеукраїнських та міжнародних фестивалях та конкурсах.

Так, у 2012 р. У. Перхалюк (свого часу випускниця, а сьогодні викладач ТКМК) стала лауреатом III всеукраїнського конкурсу виконавців на народних, струнних, духових та ударних інструментах ім. А. Онуфрієнка (м. Дрогобич), у 2013 р. ансамбль бандуристок під Д. Губ'яка виборов звання лауреата II ступеня VI міжнародного конкурсу“"Perpetuummobile”(м. Дрогобич), лауреата III ступеня I міжнародного фестивалюконкурсу “Таврійські зустрічі” (м. Сімферополь, 2013).

Ансамбль бандуристів під його керівництвом у березні 2015 р. здійснив концертне турне у Франції, приурочене до святкуванню дня народження Т. Шевченка. Концертне турне розпочалося виступом у Страсбурзі, в Раді Європи, у присутності посла України та віцепрезидента Ради Свропи. Подібний тур у Франції відбувся і у березні 2016 р. (14 концертів у 14-ти містах) [2].

Серед 23 творів концертної програми були українські народні та авторські пісні, класична музика, джазові аранжування, пісні популярних французьких виконавців, таких як Ш. Азнавур та Е. Піаф, виконані мовою оригіналу.

У вересні 2017 р. ансамбль бандуристів ТНПУ iм. В. Гнатюка побував 3 гастролями на острові Тайвань, а у жовтні 2017 р. - взяв участь у Міжнародному фестивалі "SECOND WORLD MUSIC WEEK”, що відбувся у Китайській Народній Республіці. Колектив і сьогодні у творчому пошуку, готує нові програми, які презентуватиме в області, в Україні та за їі межами, популяризуючи таким чином національний музичний інструментарій [2].

Сучасне кобзарсько-бандурне виконавство на Тернопіллі представлене як солістами (В. Жданкін, Д. Губ'як, Ю. Баришовець, Н. Кулик та ін.), так і учасниками малих форм: знаний свого часу ансамбль “Ватрівчани", тріо “Оріана" (згодом квартет), “Роксолани”, “Стрітення” ТОО НСКУ, дует "Елегія струн”, організований при ТОКЕШМ ім. І. Герети, та ін.), згаданими вище 
ансамблями та капелами при районних будинках культури, мистецьких навчальних закладах та ін. [4].

Традиційними для Тернопільщини стали дитячі конкурси-огляди серед учнів ДМШ, шкіл мистецтв та естетичного виховання: “Творчість юних", "Надія”, “Юні таланти”, конкурс камерних ансамблів “Консонанс" та конкурс дитячої композиторської творчості.

Висновки. Проведений огляд соціокультурного та навчально-освітнього аспектів розвитку та популяризації виконавства на народних інструментах, зокрема на Тернопіллі, дозволяє дійти наступних висновків. Сучасне виконавське мистецтво краю, сконцентроване навколо культурно-мистецьких та закладів вищої освіти області, розвивається в руслі загальних мистецьких та культурно-освітніх процесів, фестивального руху. Активним стає використання виконавства на народних інструментах у тематичних філармонічних концертних програмах, у драматичних постановках театру, у різних мистецьких акціях.

Усі перелічені чинники сприяють популяризації виконавства на народних інструментах у фаховій освітній галузі, у молодіжному середовищі, у широкій слухацькій аудиторії, засвідчують перспективність цього виду виконавського мистецтва, який вносить “національно забарвлений компонент” у сфери академічної та масової музичної культури, стає репрезентантом національного мистецтва у світовому культурному просторі.

\section{ЛІТЕРАТУРА}

1. Губ’як Д. Грай, “Кобзарю!” . Львів, 2010. $280 \mathrm{c}$.

2. Губ’як Д., Гринчук I. Концертна та просвітницька діяльність студентів-бандуристів ТНПУ ім. В. Гнатюка. Мистецька діяльність у сучасному соціокультурному просторі (25-літній творчий внесок факультету мистецтв Тернопільського національного педагогічного університету ім. В. Гнатюка): колективна монографія / за заг. ред. Б.О. Водяного та ін. Тернопіль, 2018. С. $296-303$.

3. Давидов М. Історія виконавства на народних інструментах (Українська академічна школа) : підруч. вид. 2-ге, доп., випр. Київ, 2010.592 с.

4. Капелибандуристів Тернопільщини/М. Свгеньєва. TEC : у 4 т. Тернопіль, 2005. Т. 2 : К - О. С. 28.

5. Лісняк I. Сучасний вимір бандурного мистецтва. Орієнтири ансамблевої творчості. Музична україністика : сучасний вимір : зб. наук. ст. на пошану А. Терещенко / ред.-упоряд. М. Ржевська-Київ; Івано-Франківськ,2008. Вип. 2. C. $329-335$.

\section{REFERENCES}

1. Hubyak, D. (2010). Hray, “Kobzaryu!” [Play "Kobzar!']. Lviv, 280 p. [in Ukrainian].

2. Hubyak, D. \& Hrynchuk, I. (2018). Kontsertna ta prosvitnytska diyalnist studentiv-bandurystiv TNPU im. V. Hnatyuka [Concert and educational activities of student-bandura students of TNPU them. V. Hnatyuk]. Artistic activity in the modern sociocultural space (the 25-year creative contribution of the Faculty of Arts of the Ternopil National Pedagogical University named after V. Hnatyuk): a collective monograph. Ternopil, pp. 296 - 303. [in Ukrainian].

3. Davydov, M. (2010). Istoriya vykonavstva na narodnykh instrumentakh (Ukrayinska akademichna shkola) [History of Performing on Folk Instruments (Ukrainian Academic School)]. subhead. kind. 2nd, additional, vers. Kyiv, 592 p. [in Ukrainian].

4. Yevhenyeva, M. (2005). Kapely bandurystiv Ternopilshchyny [Chapels of bandura players of Ternopil region]. Ternopil. Vol. 2, p. 28. [in Ukrainian].

5. Lisnyak, I. (2008). Suchasnyy vymir bandurnoho mystetstva. Oriyentyry ansamblevoyi tvorchosti [Contemporary dimension of bandura art. Landmarks of ensemble art]. Musical Ukrainian Studies: Modern Dimension: op. sciences Art. in honor of A. Tereshchenko / ed.-order. M. Rzhevskaya. Kyiv; Ivano-Frankivsk. Vol. 2, pp. 329 - 335. [in Ukrainian].

Стаття надійшла до редакції 28.02.2019

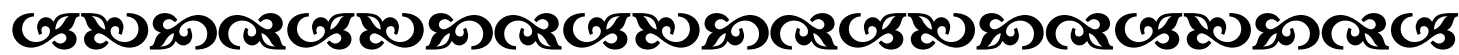

“Дюдина повинна навчитися підкорятись самій собі і скорятися своїм рішенням". भुиерон

давнъоримсъкий політичний діяч

"Якщо ви досягли вершини - піднімайтесь вище”. 